\title{
Jurnal
}

p-ISSN 2621-797X ; e-ISSN 2746-6841 DOI:10.32493

Jurnal Disrupsi Bisnis, Vol. 4, No.3, Mei 2021 (252- 258)

http://openjournal.unpam.ac.id/index.php/DRB/index

\section{Analisis Strategi Pemasaran Dalam Meningkatkan Volume Penjualan Pada UD. Jaya Marine Surabaya}

\author{
Stephanie Ceicillia ${ }^{1 *}$, Budi Prabowo ${ }^{2}$ \\ ${ }^{1,2}$ Fakultas Ilmu Sosial dan Ilmu Politik, UPN Veteran Jawa Timur \\ ${ }^{1}$ ceicillia98@gmail.com*; bprabowo621@gmail.com
}

Received 11 Mei 2021| Revised 12 Mei 2021 | Accepted 20 Mei 2021

*Korespondensi Penulis

\begin{abstract}
Abstrak
Tujuan peneliti melakukan penelitian ini ialah untuk mengetahui strategi pemasaran yang digunakan oleh UD. Jaya Marine Surabaya dalam meningkatkan penjualannya. Penelitian ini menggunakan jenis penelitian kuantitatif dengan pendekatan deskripstif. Pengumpulan informasi dilakukan dengan menggunakan metode wawancara, observasi, dan juga dokumentasi. Informasi yang didapatkan diolah dan diidentifikasi menggunakan teknik Analisis SWOT. Hasil analisis SWOT pada UD. Jaya Marine Surabaya menunjukkan bahwa usaha tersebut memiliki kekuatan yang memadai untuk bisa memanfaatkan peluang yang ada. Strategi yang dapat digunakan oleh usaha ini ialah sering melakukan analisis pada kebutuhan dan juga perilaku konsumen, meningkatkan kualitas pelayanan yang diberikan demi kepuasan pelanggan, semakin masif melakukan kegiatan promosi pada sosial media, dan juga bisa melakukan penjualan online secara aktif melalui platform penjualan online yang telah ada.
\end{abstract}

Kata Kunci: Strategi Pemasaran; Analisis SWOT; Penjualan

\begin{abstract}
The purpose of this study is to determine the marketing strategy used by UD. Jaya Marine Surabaya to increasing sales using SWOT analysis techniques. This research uses quantitative research with a descriptive approach. Information gathering is done by using interview, observation, and documentation methods. The information obtained is processed and identified using the SWOT analysis technique. The results of the SWOT analysis show that the business sufficient strength to be able to take advantage of existing opportunities. Strategies that can be used by this business are to frequently analyze the needs and behavior of consumers, improve the quality of service provided to customers satisfaction, carry out more massive promotional activities on social media, and also be able to actively sell online through existing online sales platforms.
\end{abstract}

Keywords: Marketing strategy; SWOT analysis; Sales

\section{PENDAHULUAN}

Perkembangan ekonomi di Indonesia saat ini terus mengalami peningkatan, sehingga pemerintah terus berupaya memperbaiki sistem perekonomian negara menjadi lebih baik lagi. Berbagai upaya dilakukan, salah satunya ialah pembangunan dan juga pengembangan infrastruktur. Pembangunan tersebut ternyata mengakibatkan jumlah kecelakaan akibat kerja mengalami peningkatan. Sehingga pemerintah berupaya melakukan pengawasan dengan memwajibkan pekeja mengenakan alat pelindung diri. Hal ini tentunya membuka peluang usaha bagi para pengusaha dan membuat bermunculah pesaing- 
pesaing yang menjual produk yang sejenis. Strategi pemasaran UD. Jaya Marine Surabaya haruslah tepat untuk bisa terus bersaing dengan kompetitor lainnya dan mampu meningkatkan pendapatannya.

Penelitian ini menganalisis strategi pemasaran dalam meningkatkan volume penjualan pada UD. Jaya Marine Surabaya. Dan penelitian ini bertujuan untuk mengetahui strategi pemasaran yang digunakan oleh UD. Jaya Marine Surabaya dalam meningkatkan volume penjualannya.

\section{Strategi Pemasaran}

Menurut Kotler dan Amstrong (2014: 72), strategi pemasaran merupakan logika pemasaran yang dapat digunakan oleh perusahaan dengan harapan agar unit bisnis dapat mencapai tujuan perusahaan. Menurut Corey dalam buku Fandy Tjiptono (2015), strategi pemasaran terdiri atas lima elemen yang saling berkaitan, yaitu pemilihan pasar, perencanaan produk, penetapan harga, sistem distribusi, dan komunikasi pemasaran. Secara lebih rinci, Walker dan kawan-kawannya menjabarkan bahwa strategi yang baik (termasuk strategi pemasaran) wajib memiliki lima komponen pokok. Kelima komponen tersebut adalah sebagai berikut:

1. Lingkup (scope), yaitu cakupan domain strategik, seperti jumlah tipe industri, lini produk dan segmen pasar yang dimasuki atau direncanakan untuk dimasuki

2. Tujuan dan sasaran, menyangkut tingkat pencapaian yang diharapkan berdasarkan satu atau lebih dimensi kerja (seperti pertumbuhan volume penjualan, kontribusi laba, atau Return on Investment) selama periode waktu tertentu bagi setiap bisnis dan pasar produk, serta bagi organisasi secara keseluruhan.

3. Pengalokasian sumber daya (terutama sumber daya manusia dan finansial) untuk berbagi bisnis, pasar produk, departemen fungsioanl, dan aktivitas dalam masing-masing bisnsi atau pasar produk.

4. Identifikasi keunggulan kompetitif berkesinambungan, yang mampu menjabarkan cara organisasi bersaing dengan para pesaing saat ini dan pesaing potensial.

5. Sinergi antar bisnis, pasar produk, pengalokasian sumber daya, dan kompetensi.

\section{Penjualan}

Definisi penjualan menurut Mulyadi (2016) ialah penjualan sebuah kegiatan yang dilakukan oleh penjual dalam menjual barang dan jasa dengan impian akan mendapatkan laba dari terdapatnya transaksi-transaksi tersebut dan penjualan bisa diartikan sebagai mengalihkan atau memindahkan hak kepemilikan atas barang atau jasa dari pihak penjual kepada pihak pembeli.

\section{METODE}

Penelitian ini dilakukan pada UD. Jaya Marine Surabaya merupakan usaha yang bergerak dalam bidang alat kesehatan dan keselamatan kerja atau K3, beralamatkan pada jalan Kusuma Bangsa Nomor 55 Kota Surabaya. Dengan menggunakan teknik pengambilan sampel yaitu purposive sampling. Sampel pada penelitian ini ialah pemilik, karyawan, dan juga konsumen. Metode penelitian yang digunakan dalam penelitian ini adalah metode kuantitatif. Pengumpulan data dilakukan dengan melakukan wawancara kepada informan penelitian yaitu pemilik, karyawan, dan konsumen. Analisis data yang digunakan dalam penelitian yaitu analisis SWOT.

\section{HASIL DAN PEMBAHASAN}

\section{Hasil}

Dari wawancara yang telah dilakukan bersama informan dapat diketahui kekuatan, kelemahan, peluang,dan juga ancaman dari UD. Jaya Marine Surabaya sehingga dapat dijabarkan sebagai berikut :

1. Kekuatan 
a. Menjual berbagai produk kesehatan dan keselamatan kerja dengan komplit.

b. Harga yang disuguhkan bervariasi.

c. Memberikan fasilitas layanan antar barang.

d. Memberikan pelayanan yang cepat dan juga ramah.

e. Menyediakan sistem pre order.

2. Kelemahan

a. Sistem manajemen pengelolaan yang masih kurang modern.

b. Belum memiliki cabang.

c. Untuk barang-barang impor, jumlah yang tersedia masih terbatas.

d. Fasilitas tempat usaha yang masih kurang memuaskan.

e. Harga yang ditawarkan masih kalah saing dengan pesaing.

3. Peluang
a. Maraknya pembangunan yang dilaksanakan di Indonesia.
b. Kebijakan Pemerintah mengenai sistem K3 pada setiap instansi.
c. Berkembangnya dunia usaha alat k3.
d. Tempat usaha yang strategis.
e. Adanya sosial media yang dapat memudahkan pemasaran.

4. Ancaman

a. Banyaknya usaha yang sejenis.

b. Adanya pesaing dengan nama yang hampir sama.

c. Kondisi pandemi yang tak kunjung usai.

d. Harga barang relatif mengalami kenaikan.

e. Pesaing unggul dalam memanfaatkan saluran komunikasi dan juga pemasaran onlinenya.

Tahap Analisis Faktor Internal dan Faktor Eksternal dengan menggunaka tabel IFAS dan tabel EFAS

Tabel 1. IFAS (Internal Factor Analysis Summary)

\begin{tabular}{|c|c|c|c|c|c|}
\hline No. & $\begin{array}{c}\text { Faktor-faktor Strategi } \\
\text { Internal }\end{array}$ & Bobot & Rating & B $\times \mathbf{R}$ & Keterangan \\
\hline & \multicolumn{5}{|l|}{ Kekuatan } \\
\hline 1. & $\begin{array}{l}\text { Menjual produk dengan } \\
\text { komplit. }\end{array}$ & 0,20 & 4 & 0,80 & Dipertahankan \\
\hline 2. & $\begin{array}{l}\text { Harga yang ditawarkan } \\
\text { bervariasi. }\end{array}$ & 0,10 & 2 & 0,20 & Dipertahankan \\
\hline 3. & $\begin{array}{l}\text { Memberikan fasilitas } \\
\text { antar barang. }\end{array}$ & 0,05 & 1 & 0,05 & $\begin{array}{l}\text { Ditingkatkan lagi dengan } \\
\text { memberikan fasilitas tanpa } \\
\text { adanya minimum pembelian }\end{array}$ \\
\hline 4. & $\begin{array}{l}\text { Memberikan pelayanan } \\
\text { yang cepat dan ramah. }\end{array}$ & 0,13 & 3 & 0,39 & Dipertahankan. \\
\hline 5. & $\begin{array}{l}\text { Menyediakan sistem } \\
\text { pre-order }\end{array}$ & 0,06 & 2 & 0,12 & $\begin{array}{l}\text { Ditingkatkan lagi agar } \\
\text { persediaan barang tetap tersedia. }\end{array}$ \\
\hline & Total & 0,54 & & 1,56 & \\
\hline & Kelemahan & & & & \\
\hline 1. & $\begin{array}{l}\text { Sistem manajemen } \\
\text { pengelolaan kurang } \\
\text { modern. }\end{array}$ & 0,10 & 2 & 0,20 & \begin{tabular}{lr} 
Memanfaatkan & \multicolumn{2}{r}{ kecanggihan } \\
teknologi untuk bisa \\
memaksimalkan pengelolaan \\
usaha.
\end{tabular} \\
\hline
\end{tabular}




\begin{tabular}{|c|c|c|c|c|c|}
\hline No. & $\begin{array}{c}\text { Faktor-faktor Strategi } \\
\text { Internal }\end{array}$ & Bobot & Rating & $\mathbf{B} \times \mathbf{R}$ & Keterangan \\
\hline 2. & Belum memiliki cabang. & 0,05 & 1 & 0,05 & $\begin{array}{l}\text { Memperluas pangsa pasar } \\
\text { dengan membuka cabang pada } \\
\text { tempat lain sehingga bisa } \\
\text { menjamah konsumen pada } \\
\text { daerah yang berbeda dengan } \\
\text { sebelumnya. }\end{array}$ \\
\hline 3. & $\begin{array}{l}\text { Untuk barang-barang } \\
\text { impor, jumlahnya masih } \\
\text { terbatas. }\end{array}$ & 0,16 & 4 & 0,64 & $\begin{array}{l}\text { Bekerja sama dengan lebih } \\
\text { banyak lagi pemasok maupun } \\
\text { distributor barang-barang impor. }\end{array}$ \\
\hline 4. & $\begin{array}{l}\text { Fasilitas tempat usaha } \\
\text { yang masih kurang } \\
\text { memadai. }\end{array}$ & 0,05 & 1 & 0,05 & $\begin{array}{l}\text { Menyediakan lahan parkir, } \\
\text { memperluas, dan menata rapih } \\
\text { tempat usaha. }\end{array}$ \\
\hline 5. & $\begin{array}{l}\text { Harga yang ditawarkan } \\
\text { masih kalah dengan } \\
\text { pesaing. }\end{array}$ & 0,10 & 2 & 0,20 & $\begin{array}{l}\text { Harga yang dibandrol lebih } \\
\text { mahal karena disesuaikan } \\
\text { dengan bahan baku dan kualitas } \\
\text { yang digunakan dalam proses } \\
\text { produksi. }\end{array}$ \\
\hline & Total & $\mathbf{0 , 4 6}$ & & 1,14 & \\
\hline & Total Skor Internal & 1 & & 2,7 & \\
\hline
\end{tabular}

Tabel 2. EFAS (External Factor Analysis Summary)

\begin{tabular}{|c|c|c|c|c|c|}
\hline No. & $\begin{array}{c}\text { Faktor-faktor Strategi } \\
\text { Eksternal }\end{array}$ & Bobot & Rating & $\mathbf{B} \times \mathbf{R}$ & Keterangan \\
\hline & \multicolumn{5}{|l|}{ Peluang } \\
\hline 1 & $\begin{array}{l}\text { Maraknya pembangunan } \\
\text { yang dilaksanakan di } \\
\text { Indonesia. }\end{array}$ & 0,18 & 4 & 0,72 & Dipertahankan \\
\hline 2 & $\begin{array}{l}\text { Kebijakan pemerintah } \\
\text { mengenai sistem K3 pada } \\
\text { setiap instansi. }\end{array}$ & 0,12 & 3 & 0,36 & Dipertahankan \\
\hline 3 & $\begin{array}{l}\text { Berkembangnya dunia } \\
\text { usaha alat K3. }\end{array}$ & 0,06 & 2 & 0,12 & Dipertahankan \\
\hline 4 & $\begin{array}{l}\text { Tempat usaha yang } \\
\text { strategis. }\end{array}$ & 0,05 & 1 & 0,05 & Dipertahankan. \\
\hline \multirow[t]{3}{*}{5} & $\begin{array}{l}\text { Adanya sosial media yang } \\
\text { dapat memudahkan } \\
\text { pemasaran. }\end{array}$ & 0,10 & 2 & 0,20 & Dipertahankan \\
\hline & Total & $\mathbf{0 , 5 1}$ & & 1,45 & \\
\hline & Ancaman & & & & \\
\hline 1 & $\begin{array}{l}\text { Banyaknya usaha yang } \\
\text { sejenis. }\end{array}$ & 0,07 & 2 & 0,14 & $\begin{array}{l}\text { Meningkatkan kualitas produk } \\
\text { dan juga pelayanan. }\end{array}$ \\
\hline 2 & $\begin{array}{l}\text { Adanya pesaing dengan } \\
\text { nama yang hampir sama. }\end{array}$ & 0,09 & 2 & 0,18 & $\begin{array}{l}\text { Menciptakan ciri khas usaha } \\
\text { dan juga lebih memberikan } \\
\text { informasi usaha pada sosial } \\
\text { media. }\end{array}$ \\
\hline 3 & $\begin{array}{l}\text { Kondisi pandemi yang tak } \\
\text { kunjung usai. }\end{array}$ & 0,11 & 3 & 0,33 & $\begin{array}{l}\text { Merubah fokus usaha pada } \\
\text { jenis barang tertentu yang } \\
\text { masih dibutuhkan. }\end{array}$ \\
\hline 4 & $\begin{array}{l}\text { Harga barang relatif } \\
\text { mengalami kenaikan. }\end{array}$ & 0,06 & 2 & 0,12 & $\begin{array}{l}\text { Mencari barang substitusi atau } \\
\text { barang pengganti. }\end{array}$ \\
\hline 5 & $\begin{array}{lr}\text { Pesaing unggul } & \text { dalam } \\
\text { memanfaatkan } & \text { saluran }\end{array}$ & 0,16 & 4 & 0,64 & \begin{tabular}{lcc} 
Aktif dalam & \multicolumn{2}{c}{ menggunakan } \\
sosial media sebagai media
\end{tabular} \\
\hline
\end{tabular}




\begin{tabular}{ccccc}
\hline No. $\begin{array}{c}\text { Faktor-faktor Strategi } \\
\text { Eksternal }\end{array}$ & Bobot & Rating & B x R & Keterangan \\
\hline $\begin{array}{l}\text { komunikasi dan juga } \\
\text { pemasaran onlinenya. }\end{array}$ & & & $\begin{array}{l}\text { promosi dan juga komunikasi } \\
\text { dengan pelanggan. }\end{array}$ \\
\hline Total & $\mathbf{0 , 4 9}$ & $\mathbf{1 , 4 1}$ & \\
\hline Total Skor Internal & $\mathbf{1}$ & $\mathbf{2 , 8 6}$ & \\
\hline
\end{tabular}

Diagram Analisis SWOT

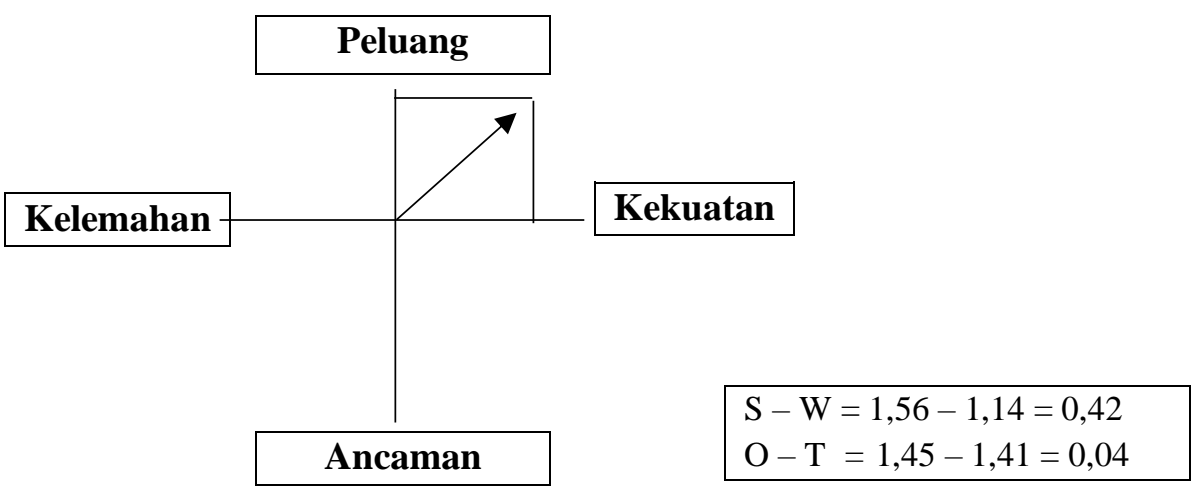

Gambar 1. Diagram Analisis SWOT

Dari hasil diagram analisis SWOT diatas diketahui bahwa UD. Jaya Marine Surabaya masih berada pada kuadran I (satu) yang mana usaha tersebut memiliki peluang yang cukup tinggi dan kekuatan yang memadai yang mampu memanfaatkan dengan baik peluang-peluang yang ada. Strategi yang dapat dilakukan apabila suatu usaha berada pada kuadran tersebut ialah dengan mendukung kebijakan strategi agresif.

Rumusan Strategi Matriks SWOT

Tabel 3. Rumusan Strategi Matriks SWOT

\begin{tabular}{|c|c|c|}
\hline IFAS & Kekuatan & Kelemahan \\
\hline Peluang & $\begin{array}{c}\text { Strategi SO } \\
1,56+1,45=3,01\end{array}$ & $\begin{array}{c}\text { Strategi SW } \\
1,14+1,45=2,59\end{array}$ \\
\hline Ancaman & $\begin{array}{c}\text { Strategi ST } \\
1,56+1,41=2,97\end{array}$ & $\begin{array}{c}\text { Strategi WT } \\
1,14+1,41=2,55\end{array}$ \\
\hline
\end{tabular}

Perencanaan Kombinasi Strategi SWOT

Tabel 4. RPerencanaan Kombinasi Strategi SWOT

\begin{tabular}{|c|c|c|}
\hline EFAS IFAS & Kekuatan & Kelemahan \\
\hline Peluang & $\begin{array}{l}\text { Strategi SO } \\
\text { Menggunakan Kekuatan } \\
\text { dengan memanfaatkan } \\
\text { Peluang= 3,01 }\end{array}$ & $\begin{array}{l}\quad \text { Strategi WO } \\
\text { Meminimalkan Kelemahan } \\
\text { untuk memanfaatkan Peluang } \\
=2,59\end{array}$ \\
\hline Ancaman & \begin{tabular}{l}
\multicolumn{1}{c}{ Strategi ST } \\
Menggunakan Kekuatan \\
untuk mengatasi \\
Ancaman=2,97
\end{tabular} & \begin{tabular}{l}
\multicolumn{1}{c}{ Strategi WT } \\
Meminimalkan Kelemahan \\
untuk menghindari \\
Ancaman $=2,55$
\end{tabular} \\
\hline
\end{tabular}




\section{Matriks SWOT}

Tabel 5. Matriks SWOT

\begin{tabular}{|c|c|c|}
\hline EFAS & $\begin{array}{l}\text { Kekuatan } \\
\text { 1. Menjual produk dengan } \\
\text { komplit. } \\
\text { 2. Harga yang ditawarkan } \\
\text { bervariasi. } \\
\text { 3. Memberikan fasilitas antar } \\
\text { barang. } \\
\text { 4. Memberikan pelayanan } \\
\text { yang cepat dan ramah. } \\
\text { 5. Menyediakan sistem pre } \\
\text { order. }\end{array}$ & $\begin{array}{l}\text { Kelemahan } \\
\text { 1. Sistem manajemen } \\
\text { pengelolaan yang masih } \\
\text { kurang modern. } \\
\text { 2. Belum memiliki cabang. } \\
\text { 3. Untuk barang-barang impor, } \\
\text { jumlahnya masih terbatas. } \\
\text { 4. Fasilitas tempat usaha yang } \\
\text { masih kurang memadai. } \\
\text { 5. Harga yang ditawarkan } \\
\text { masih kalah dengan pesaing. }\end{array}$ \\
\hline $\begin{array}{ll}\text { Peluang } \\
\text { 1. } & \text { Maraknya pembangunan } \\
\text { yang dilaksanakan di } \\
\text { Indonesia. } \\
\text { 2. Kebijakan pemerintah } \\
\text { mengenai sistem K3 pada } \\
\text { tiap instansi. } \\
\text { 3. Berkembangnya dunia } \\
\text { usaha alat K3. } \\
\text { 4. Tempat usaha yang } \\
\text { strategis. } \\
\text { 5. Adanya sosial media yang } \\
\text { dapat memudahkan } \\
\text { pemasaran. }\end{array}$ & $\begin{array}{l}\text { Strategi SO (Adanya } \\
\text { kekuatan untuk } \\
\text { memanfaatkan peluang) } \\
\text { 1. Mengupdate secara berkala } \\
\text { apa saja yang sedang } \\
\text { dibutuhkan pelanggan. } \\
\text { 2. Meningkatkan kualitas } \\
\text { pelayanan yang diberikan } \\
\text { kepada pelanggan. } \\
\text { 3. Semakin masif melakukan } \\
\text { promosi pada sosial media. } \\
\text { 4. Semakin aktif melakukan } \\
\text { penjualan online. }\end{array}$ & $\begin{array}{l}\text { Strategi WO (Meminimalisir } \\
\text { kelemahan untuk } \\
\text { memanfaatkan peluang yang } \\
\text { ada) } \\
\text { 1. Mulai memanfaatkan } \\
\text { kecanggihan teknologi } \\
\text { dalam mengelola usaha. } \\
\text { 2. Memperkaya channel pada } \\
\text { pemasok dan juga distributor } \\
\text { untuk memenuhi kebutuhan } \\
\text { persediaan barang. } \\
\text { 3. Memperluas dan juga } \\
\text { menata tata ruang supaya } \\
\text { rapi sehingga pelanggan } \\
\text { merasa nyaman. }\end{array}$ \\
\hline $\begin{array}{ll}\text { Ancaman } \\
\text { 1. } & \text { Banyak usaha yang sejenis. } \\
\text { 2. } & \text { Adanya pesaing dengan } \\
\text { nama yang hampir sama. } \\
\text { 3. Kondisi pandemi yang tak } \\
\text { kunjung usai. } \\
\text { 4. Harga barang relatif } \\
\text { mengalami kenaikan. } \\
\text { 5. Pesaing unggul dalam } \\
\text { memanfaatkan saluran } \\
\text { komunikasi dan juga } \\
\text { pemasaran onlinenya. }\end{array}$ & $\begin{array}{l}\text { Strategi ST (menggunakan } \\
\text { kekuatan untuk mengatasi } \\
\text { ancaman) } \\
\text { 1. Menjaga kepercayaan } \\
\text { pelanggan. } \\
\text { 2. Selalu mengecek persediaan } \\
\text { barang yang ada. } \\
\text { 3. Fokus usaha pada barang- } \\
\text { barang yang saat ini } \\
\text { dibutuhkan. }\end{array}$ & $\begin{array}{l}\text { Strategi WT (meminimalkan } \\
\text { kelemahan untuk } \\
\text { menghindari ancaman) } \\
\text { 1. Menampung segala bentuk } \\
\text { kritikan yang diberikan oleh } \\
\text { pelanggan dan mengadakan } \\
\text { evaluasi dengan team. } \\
\text { 2. Melengkapi fasilitas } \\
\text { pendukung pada tempat } \\
\text { usaha. }\end{array}$ \\
\hline
\end{tabular}

\section{Pembahasan}

\section{Strategi Pemasaran}

\section{Produk}

Produk yang ditawarkan oleh UD. Jaya Marine Surabaya ialah alat-alat kesehatan dan keselamatan kerja, menyediakan berbagai macam jenis, merek, kualitas, dan asal merek produk (lokal maupun impor). Kualitas yang ditawarkan juga sangat terjamin karena menyediakan berbagai pilihan merek yang sudah terpercaya dan beberapa merek yang berasal dari luar negeri seperti Cina, Jepang, Vietnam hingga Jerman. Produk yang menjadi andalan dan best seller ialah helm dan juga rompi.

2. Harga

Penentuan harga sendiri berdasarkan pada harga yang diberikan oleh supplier ataupun distributor. Harga yang ditawarkan oleh UD. Jaya Marine Surabaya sangatlah bervariasi disesuaikan dengan kualifikasi barang yaitu berdasarkan kualitas maupun legalitas SNI (standar nasional Indonesia).

\section{Promosi}


Kegiatan promosi yang dilakukan hanya sebatas memberikan informasi lokasi usaha dan juga nomor telpon yang dimuat dalam google. UD. Jaya Marine Surabaya melakukan kegiatan promosinya melalui whatsApp dengan membuat story (cerita) yang memuat barang-barang yang dijual, atau langsung menawarkan pada beberapa pelanggan tetap melalui personal chat.

4. Tempat

Tempat usaha yang saat ini ditempati oleh UD. Jaya Marine Surabaya dikatakan strategis karena berada pada tengah atau pusat kota dan juga posisi toko yang berada pada pinggir jalan raya. Tempat usaha tersebut didukung dengan beberapa fasilitas tambahan seperti listrik, tempat duduk, dan juga parkiran.

Formulasi Strategi

Berdasarkan hasil analisis yang sudah dilakukan dengan menggunakan teknik analisis SWOT sesuai dengan teori (Freddy Rangkuti: 2013), diketahui bahwa UD. Jaya Marine Surabaya berada pada kuadran I (satu) yang mana perusahaan menggunakan ataupun memaksimalkan kekuatan dari dalam perusahaan untuk menghadapi berbagai ancaman yang datang dari luar perusahaan.

Strategi yang dapat diimplementasikan oleh UD. Jaya Marine Surabaya dalam meningkatkan penjualan berdasarkan strategi agresif ialah dengan terus menganalisis kebutuhan dan juga perilaku konsumen, meningkatkan kualitas layanan yang diberikan kepada pelanggan, melakukan kegiatan promosi secara masif pada sosial media untuk menjangkau lebih banyak pelanggan dan makin banyak orang yang mengenal atau mengetahui usahanya. Selain itu, melakukan pemasaran online dengan maksimal yaitu dengan membuka lapak pada berbagai platform penjualan online untuk memudahkan konsumen di luar pulau Jawa yang ingin membeli.

\section{SIMPULAN}

Berdasarkan hasil analisis yang dilakukan oleh peneliti pada UD. Jaya Marine Surabaya dapat diambil kesimpulan oleh peneliti sebagai berikut:

Hasil menunjukan bahwa pada strategi pemasaran pada UD. Jaya Marine Surabaya dengan memakai indikator 4P. Produk (Product) yang ditawarkan berupa alat-alat kesehatan dan keselamatan kerja yang menyediakan berbagai macam jenis barang, merek, kualitas, dan asal produk. Harga (Price) dalam menetapkan harga disesuaikan dengan harga yang didapat dari supplier atau distributor. Harga yang ditawarkan pada masing-masing barang bervariatif disesuaikan dengan kualifikasi kualitas.Promosi (Promotion) yang dilakukan sebatas memberikan informasi tempat usaha dan nomor telfon yang dimuat pada google, melakukan kegiatan promosi langsung pada pelanggan melalui personal kontak milik pelanggan tetapnya. Tempat (Place) tempat usaha yang strategis berada pada tengah atau pusat kota dan juga letaknya berada di pinggir jalan raya.

Dari analisis IFAS dan juga EFAS memberikan hasil pada nilai kekuatan sebesar 1,56, kelemahan sebesar 1,4, peluang sebesar 1,45, dan juga ancaman sebesar 1,41.

Hasil yang telah digambar pada diagram analisis SWOT memperlihatkan bahwa UD. Jaya Marine Surabaya berada pada posisi kuadran I (satu) yang mana posisi usaha tersebut memiliki kekuatan yang memadai untuk bisa memanfaatkan peluang yang ada.

\section{DAFTAR PUSTAKA}

Kotler, P. d. (2014). Principles of Marketin, (12th ed.). Jakarta: Erlangga.

Mintzberg, T. F. (2015). Strategi Pemasaran Edisi 4. Yogyakarta: CV. Andi Offset.

Mulyadi. (2016). Sistem Infomasi Akuntansi. Jakarta: Salemba Empat.

Rangkuti, F. (2013). Teknik Membedah Kasus Bisnis Analisis SWOT Cara Perhitungan Bobot, Rating, dan OCAI. Jakarta: PT. Gramedia Pustaka Utama. 